\title{
Curcumin suppresses colon cancer cell invasion via AMPK-induced inhibition of NF-кB, uPA activator and MMP9
}

\author{
WEIHUA TONG, QUAN WANG, DONGHUI SUN and JIAN SUO \\ Department of Gastrointestinal-Colorectal Surgery, First Hospital of Jilin University, Changchun, Jilin 130021, P.R. China
}

Received April 6, 2015; Accepted July 1, 2016

DOI: $10.3892 / 01.2016 .5148$

\begin{abstract}
Curcumin, an active nontoxic ingredient of turmeric, possesses potent anti-inflammatory, antioxidant and anti-cancer properties; however, the molecular mechanisms of curcumin are not fully understood. The transcription factor nuclear factor- $\kappa \mathrm{B}$ $(\mathrm{NF}-\kappa \mathrm{B})$ is key in cellular processes, and the expression/activation of urokinase-type plasminogen activator (uPA) and matrix metalloproteinase-9 (MMP9) are crucial for cell invasion. The present study investigated the hypothesis that curcumin inhibits colon cancer cell invasion by modulating NF- $\mathrm{NB}-$ mediated expression and activation of uPA and MMP9. Human colon cancer SW480 and LoVo cells were treated with various concentrations of curcumin. Curcumin was demonstrated to dose-dependently inhibit the adhesion and proliferation ability of LoVo and SW480 cells using Transwell and MTT assays, respectively. In addition, curcumin activated 5' AMP-activated protein kinase (AMPK) and suppressed p65 NF- $\kappa \mathrm{B}$ phosphorylation, as shown by western blot analysis. Compound $\mathrm{C}$, a potent AMPK inhibitor, abolished curcumin-induced inhibition of $\mathrm{NF}-\kappa \mathrm{B}$, uPA and MMP9, suggesting that AMPK activation is responsible for curcumin-mediated $\mathrm{NF}-\kappa \mathrm{B}$, uPA and MMP9 inhibition. The binding activity of $\mathrm{NF}-\kappa \mathrm{B}$ to DNA was examined and western blotting and quantitative polymerase reaction was performed to detect the effect of curcumin on the expression of UPA and MMP9. The present results revealed that curcumin significantly decreased the expression of UPA and MMP9 and $\mathrm{NF}-\kappa \mathrm{B}$ DNA binding activity. Furthermore, curcumin decreased the level of the p65 subunit of NF- $\kappa \mathrm{B}$ binding to the promoter of the gene encoding UPA and MMP9, which suppressed transcriptional activation of UPA and MMP9. Overall, the present data suggest that curcumin inhibits colon cancer cell invasion via AMPK activation and subsequent inhibition of p65 NF- $\mathrm{B}$, uPA and MMP9. The therapeutic potential of curcumin for colon cancer metastasis required additional study.
\end{abstract}

Correspondence to: Professor Jian Suo, Department of Gastrointestinal-Colorectal Surgery, First Hospital of Jilin University, 71 Xin Min Street, Changchun, Jilin 130021, P.R. China E-mail: suojian42@163.com

Key words: curcumin, colon cancer, nuclear factor-kB, urokinase-type plaminogen activator, matrix metalloproteinases

\section{Introduction}

Colorectal cancer remains the third leading cause of cancer-associated mortality in the USA, even though tremendous efforts have been made to improve the effectiveness of treatment (1). Morbidity primarily results from the growth of metastatic tumors in distant organs, and metastasis is one of the major causes of mortality in cancer patients. Multiple steps are involved in the metastatic process. One of the first steps is the invasion of cancer cells through the basement membrane via the adhesion of cancer cells to the extracellular matrix $(\mathrm{ECM})$, followed by degradation of the ECM by proteolytic enzymes (2). Key proteases that degrade the ECM are the serine proteases (plasmins), urokinase plasminogen activator (uPA), cathepsins and matrix metalloproteinases (MMPs). It is well demonstrated that UPA and MMPs are significant in tumor growth, invasion and metastasis (3-5). uPA, a member of the serine proteases, interacts with the uPA receptor, which modulates various biological functions, including cell migration, differentiation and wound healing (6). Expression of uPA is critical in cancer cell metastasis and is involved in cancer cell adhesion and invasion (4,7). MMP9 is also crucial in tumor invasion and angiogenesis, since it mediates the degradation of the ECM (8). Overexpression of MMP9 may be one step in the multi-step process that results in neoplastic cell proliferation and metastasis, and it has been demonstrated that MMP9 is associated with colorectal carcinoma (9). Therefore, inhibition of ECM degradation enzymes and cell adhesion to the ECM should be considered as preventative treatment for cancer metastasis $(5,10,11)$.

Numerous studies have suggested that nuclear factor- $\mathrm{K} \mathrm{B}$ $(\mathrm{NF}-\mathrm{\kappa B})$ is key in regulating a number of cellular processes, including inflammation, cellular proliferation, transformation and tumorigenesis $(12,13)$. NF- $\kappa \mathrm{B}$ is a ubiquitous eukaryotic transcription factor, which is identified in the cytoplasm as an inactive heterotrimer consisting of p50,p65 and IкB $\alpha$ subunits. Activation of NF- $\mathrm{KB}$ is initiated by the signal-induced degradation of I $\kappa B$ proteins, the most studied of which is I $\kappa B \alpha$. Iк $\mathrm{B} \alpha$ undergoes phosphorylation and ubiquitination-dependent degradation via activation of IкB kinase (IKK), which is composed of IKK $\alpha, \operatorname{IKK} \beta$ and IKK $\gamma$ (also referred to as NEMO) $(14,15)$. I $\kappa \beta \alpha$ phosphorylation/degradation leads to $\mathrm{NF}-\kappa \mathrm{B}$ release, which translocates to the nucleus where it acts as a transcription factor and binds to a specific consensus sequence in DNA, leading to gene transcription (16). 
Nontraditional medicine is becoming an increasingly attractive approach for the treatment of various inflammatory disorders among patients unresponsive or unwilling to receive standard medications. Curcumin is the major constituent of turmeric powder extracted from the roots of the East Indian plant Curcuma longa. It has been widely used in therapeutic preparations for centuries owing to its anti-inflammatory and chemotherapeutic properties $(17,18)$. Curcumin presents itself as a pharmacologically safe and effective potential candidate for anti-metastatic therapy, due to the following reasons: Curcumin has been demonstrated to suppress NF- $\mathrm{KB}$ activation induced by various inflammatory stimuli $(19,20)$; increasing evidence indicates that curcumin has anticancer effects against various types of human tumor cells, including ovarian, breast and colon cancer and astroglioma (21-25); curcumin has been revealed to downregulate the expression of various NF- $\mathrm{kB}$-regulated genes, including B-cell lymphoma 2, cyclooxygenase 2, tumor necrosis factor and adhesion molecules $(19,20,26-29)$; administration of curcumin in humans is safe $(17,18,30)$.

However, whether curcumin is involved in the regulation of colon cancer cell invasion via the NF- $\mathrm{KB}$ signaling pathway is not well elucidated. The present study investigated the human colon cancer LoVo and SW480 cell lines to identify the effects and mechanisms of curcumin on colon cancer cell adhesion and invasion during the metastasis process via the NF- $\kappa B$ signaling pathway. The present results demonstrated that curcumin inhibits the adhesion and invasion of colon cancer cells by suppressing the activation of NF- $\mathrm{KB}$ and IKK activity. This led to the downregulation of the expression of uPA and MMP9, which are regulated by NF- $\kappa B$, and thus suppressed the proliferation of colon cancer cells.

\section{Materials and methods}

Materials. Curcumin (diferuloylmethane) was obtained from Sigma-Aldrich (St. Louis, MO, USA), and was dissolved in dimethyl sulfoxide (DMSO) as a $10 \mathrm{mM}$ stock solution and stored at $-20^{\circ} \mathrm{C}$ for further study. Primary antibodies consisted of mouse anti-human monoclonal uPA (catalog no. sc-59727; dilution, 1:1,000) purchased from Santa Cruz Biotechnology, Inc., (Dallas, TX, USA) and rat anti-human polyclonal MMP9 (catalog no. 3852; dilution, 1:1,000), mouse anti-human monoclonal NF-кB p65 (catalog no. 6956; dilution, 1:1,000), rabbit anti-human polyclonal NF-kB p50 (catalog no. 3035; dilution, 1:1,000), rabbit anti-human polyclonal p-p65 (catalog no. 3031; dilution, 1:1,000), mouse anti-human monoclonal IKK (catalog no. 11930; dilution, 1:1,000), rabbit anti-human polyclonal AMPK (catalog no. 2532; dilution, 1:1,000), rabbit anti-human monoclonal p-AMPK (catalog no. 2535; dilution, 1:1,000) and mouse anti-human monoclonal $\beta$-actin (catalog no. 3700; dilution, 1:1,000) purchased from Cell Signaling Technology, Inc. (Danvers, MA, USA). Compound C was purchased from EMD Millipore (Billerica, MA, USA).

Cell culture. Two human colon cancer cell lines SW480 and LoVo were purchased from the American Type Culture Collection (Manassas, VA, USA). The SW480 cell line was cultured in Dulbecco's modified Eagle's medium (Thermo Fisher Scientific, Inc., Waltham, MA, USA) containing glucose $(4.5 \mathrm{~g} / \mathrm{l})$ supplemented with $10 \%$ fetal calf serum (FCS; Thermo Fisher
Scientific, Inc.), $100 \mu \mathrm{g} / \mathrm{ml}$ streptomycin and $100 \mathrm{U} / \mathrm{ml}$ penicillin. The LoVo cell line was grown in F-12 medium (Thermo Fisher Scientific, Inc.) containing L-glutamine, supplemented with $10 \%$ FCS, $100 \mu \mathrm{g} / \mathrm{ml}$ streptomycin and $100 \mathrm{U} / \mathrm{ml}$ penicillin. All cells were cultured in a humidified atmosphere of $5 \% \mathrm{CO}_{2}$ at $37^{\circ} \mathrm{C}$.

3-(4,5-dimethylthiazol-2-yl)-2,5-diphenyl tetrazolium bromide (MTT) assay. MTT proliferation assay was performed to assess the cytotoxicity of curcumin in SW480 and LoVo cells. Briefly, cells were seeded on a 96-well plate at a density of 5,000 cells/well. Following attachment, various concentrations of curcumin $(0,0.01,0.1,1,10,20$ and $50 \mu \mathrm{M})$ were added for $24 \mathrm{~h}$. The cells were washed with phosphate-buffered saline (PBS) and incubated with $200 \mu 1$ MTT $(0.5 \mathrm{mg} / \mathrm{ml})$ until formazan had formed. Subsequently, the medium was removed and formazan was dissolved with DMSO. Absorbance was measured at $570 \mathrm{~nm}$ using a microplate reader (Bio-Tek Instruments, Inc., Winooski, VT, USA). The experiment was repeated three times.

Invasion assay. A Boyden chamber (BD Biosciences, San Jose, CA, USA) was used to determine the cell invasion ability of SW480 and LoVo cells. Cells were pre-cultured in serum-free medium with or without curcumin $(0$ and $10 \mu \mathrm{M})$ for $24 \mathrm{~h}$. Cells $\left(8 \times 10^{4}\right)$ suspended in $0.5 \mathrm{ml}$ serum-free medium were loaded into the upper compartment of the invasion chamber, which was coated with Matrigel (30 mg/filter). The lower compartment was loaded with complete medium with or without curcumin. The chamber was incubated at $37^{\circ} \mathrm{C}$ for $24 \mathrm{~h}$ and the filters were removed. Invaded cells were fixed, stained and counted under a microscope. Each experiment was performed three times.

Western blotting. Western blot analysis was performed on $100 \mu \mathrm{g}$ protein extracts. SW480 and LoVo cells were lysed in lysis buffer [0.5\% sodium deoxycholate, $50 \mathrm{mM}$ Tris- $\mathrm{HCl}$ ( $\mathrm{pH}$ 7.5), $150 \mathrm{mM} \mathrm{NaCl}, 1 \%$ Nonidet P-40, $0.1 \%$ sodium dodecyl sulfate (SDS)] containing $50 \mathrm{mM} \mathrm{NaF}, 5 \mathrm{mM}$ EDTA, $1 \mathrm{mM}$ DTT and $10 \mu \mathrm{g} / \mathrm{ml}$ aprotinin. Cell lysates were resolved on SDS-polyacrylamide gel electrophoresis, according to standard protocols (31). The samples were immunoblotted with primary antibodies agaisnt uPA, MMP-9, NF-кB, IKK, p-Thr172 5' AMP-activated protein kinase (AMPK), AMPK and $\beta$-actin, followed by incubation with secondary antibodies: Goat anti-rabbit immunoglobulin $\mathrm{G}(\mathrm{IgG})$, horseradish peroxidase (HRP)-linked antibody (catalog no. 7074; dilution, 1:5,000) and horse anti-mouse IgG, HRP-linked antibody (catalog no. 7076; dilution, 1:5,000), purchased from Cell Signaling Technology Inc. Bands were visualized using an Amersham ECL Western Blotting Detection kit (GE Healthcare, Chalfont, UK), according to the manufacturer's protocol.

Quantitative polymerase chain reaction ( $q P C R$ ). Total RNA was isolated from SW480 and LoVo cells using RNA Bee RNA Isolation Reagent (Amsbio LLC, Cambridge, MA, USA). cDNA $(1 \mu \mathrm{g})$ is used as a template for subsequent PCR amplification using primers specific for MMP-9, uPA and glyceraldehyde 3-phosphate dehydrogenase (GAPDH) genes. PCR conditions were: $30 \mathrm{sec}$ at $94^{\circ} \mathrm{C}$ for denaturation, $30 \mathrm{sec}$ at $54^{\circ} \mathrm{C}$ for annealing and $30 \mathrm{sec}$ at $65^{\circ} \mathrm{C}$ for extension, for a total of 30 cycles. qPCR 

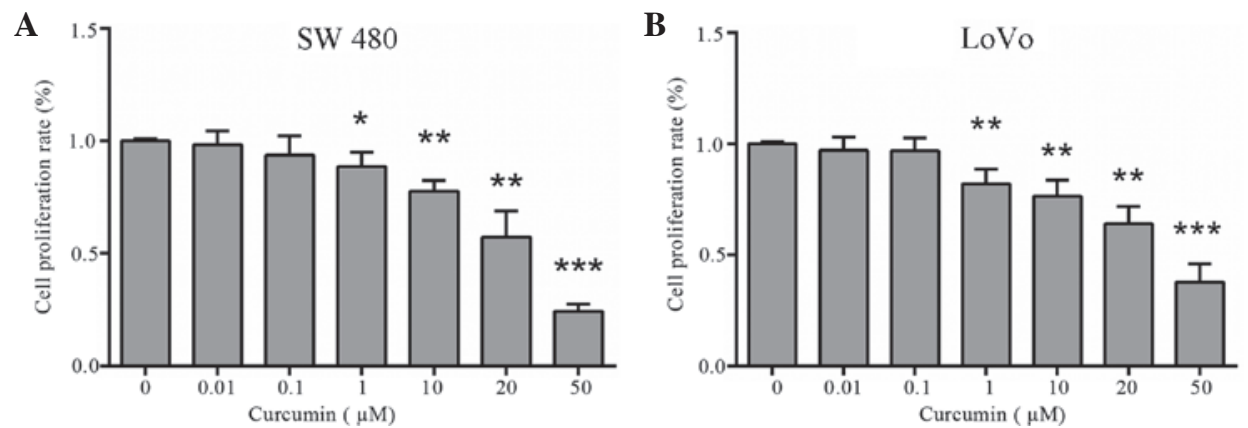

Figure 1. Cell proliferation is decreased following curcumin treatment in human colon cancer (A) SW480 and (B) LoVo cells. Cells were treated with various concentrations of curcumin $(0-50 \mu \mathrm{M})$ for $24 \mathrm{~h}$. Cell proliferation was determined using a MTT assay, and the graph shows the results of three independent experiments. The results are presented as folds over control cells (set as 1 ). ${ }^{*} \mathrm{P}<0.05 ;{ }^{* *} \mathrm{P}<0.01$ vs. control cells.

A

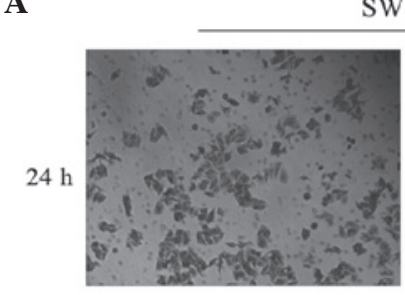

$\operatorname{Curcumin}(\mu \mathrm{M}) \quad 0$

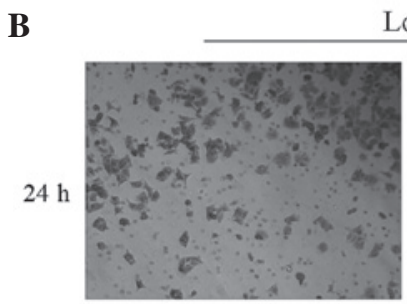

Curcumin $(\mu \mathrm{M})$
SW 480

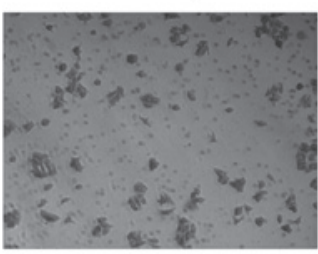

10

LoVo

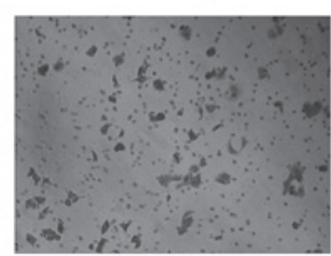

10

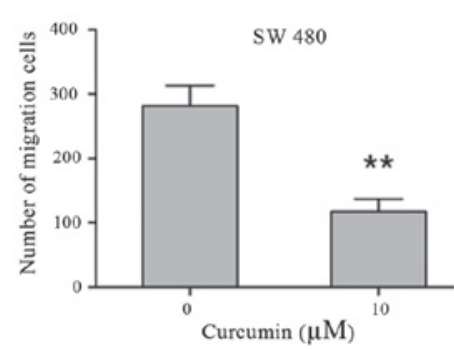

LoVo

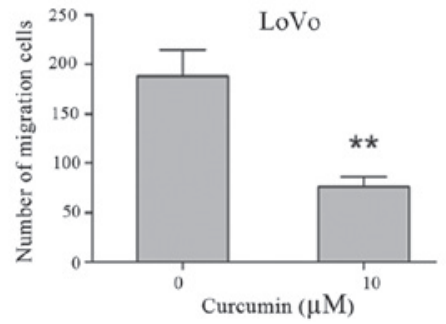

Figure 2. Effects of curcumin on cell invasion as assessed by Transwell assay. Human colon cancer SW 480 and LoVo cells suspended in serum-free Dulbecco's modified Eagle's medium were overlaid in the upper chamber of a Boyden chamber. Following incubation with curcumin $(0$ and $10 \mu \mathrm{M})$ for $24 \mathrm{~h}$, invaded cells were stained with crystal violet and recorded under a microscope. Photographs depict invasion of (A) SW480 and (B) LoVo cells. Quantified data are expressed as the mean \pm standard error of the mean from three independent experiments. ${ }^{* *} \mathrm{P}<0.01 \mathrm{vs}$. control cells.

was performed using the SYBR green real-time PCR kit (catalog no. 204141; Qiagen, Valencia, CA, USA) and the QuantStudio ${ }^{\circledR} 3$ Real-Time PCR System (Applied Biosystems ${ }^{\mathrm{TM}}$; Thermo Fisher Scientific, Inc.). PCR products were run on $2 \%$ agarose gels to confirm that correct molecular sizes were present. Each sample was tested in triplicate using qPCR. The following primers for qPCR were used: MMP9, forward 5'-AATCTCTTCTAGAGA CTGGGAAGGAG-3' and reverse 5'-AGCTGATTGACTAAA GTAGCTGGA-3'; uPA, forward 5'-CACGCAAGGGGAGAT GAA-3' and reverse 5'-ACAGCATTTTGGTGGTGACTT-3'; GAPDH, forward 5'-AGAGAGAGGCCCTCAGTTGCT-3' and reverse 5'-TTGTGAGGGAGATGCTCAGTGT-3', synthesized by BGI Tech (Shenzhen Co., Ltd., Shenzhen, China). GAPDH was used as a loading control. Quantification was performed using the $2^{-\Delta \Delta C q}$ method, as previously described (32)

Enzyme-linked immunosorbent assay (ELISA). To investigate whether curcumin affects $\mathrm{NF}-\kappa \mathrm{B}$ activation, which is critical for transcriptional activity, the DNA binding activity of NF- $\mathrm{B}$ was analyzed by ELISA. The NF- $\kappa$ B p65 Transcription Factor Assay kit (catalog no. ab133112) was purchased from Abcam
(Cambridge, MA, USA). NF- $\kappa$ B activation was measured by ELISA according to the manufacturer's protocol.

Luciferase assay. SW480 cells were seeded in 24-well plates at a density of $1 \times 10^{5}$ cells $/ \mathrm{ml} /$ well, and the following day they were co-transfected with $100 \mathrm{ng}$ luciferase reporter construct (synthesized by BGI Tech; Shenzhen Co., Ltd.), 20 ng Renilla luciferase pRL-TK reporter (Promega, Madison, WI, USA), and $400 \mathrm{ng} \mathrm{HA}$-tagged p65 NF- $\mathrm{KB}$ expression plasmid (Addgene, Cambridge, MA, USA). Subsequent to $24 \mathrm{~h}$, the cells were harvested and the luciferase activity was determined using the Dual-Luciferase ${ }^{\circledR}$ Reporter Assay System Protocol (Promega Corporation, Madison, WI, USA). The relative light units were measured using a GloMax ${ }^{\circledR}$ 20/20 Luminometer (Promega Corporation). Data were normalized by Renilla luciferase. Each experiment was performed at least three times in triplicate wells.

Statistical analysis. Data were expressed as the mean \pm standard error of the mean. Differences were analyzed by one-way analysis of variance followed by Fisher's protected least 
A

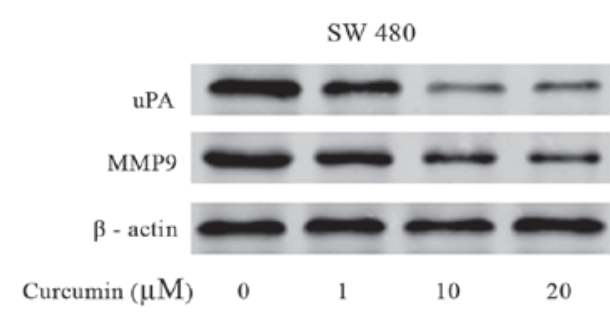

C

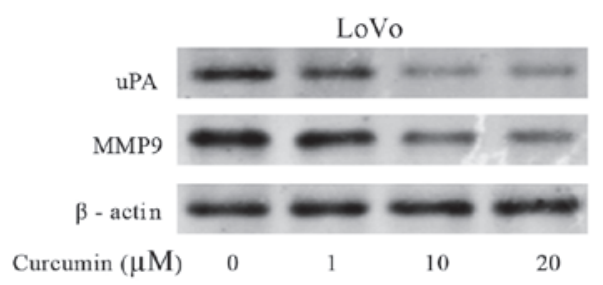

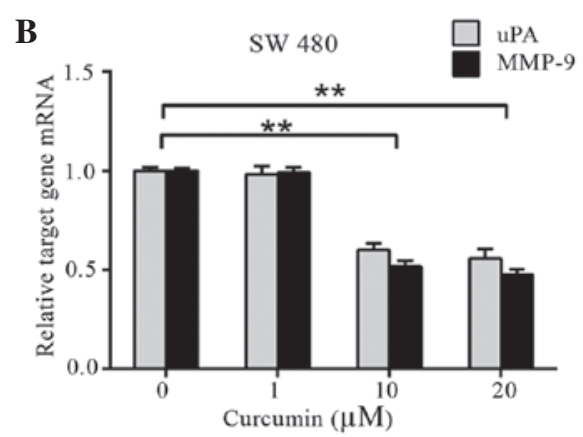

D

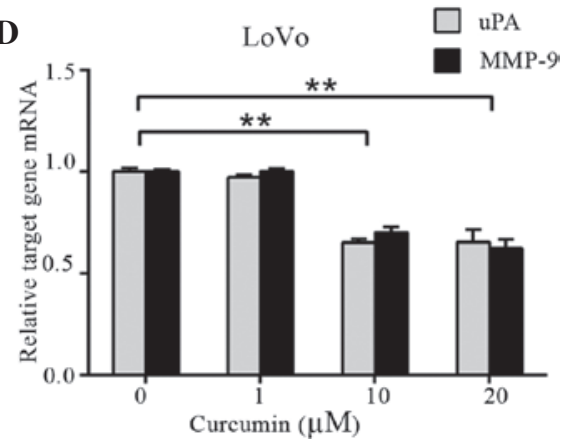

Figure 3. Effects of curcumin on uPA and MMP9 expression. Human colon cancer (A and B) SW480 and (C and D) LoVo cells were treated with curcumin $(0-20 \mu \mathrm{M})$ for $24 \mathrm{~h}$. Protein and mRNA expression of uPA and MMP9 were identified by western blotting and quantitative polymerase chain reaction, respectively. uPA and MMP9 mRNA levels in control cells were set to 1 and levels of these transcripts in the curcumin-treated groups were relative following normalization with glyceraldehyde 3-phosphate dehydrogenase. (A and C) Band weights (kDa): uPA, $52 \mathrm{kDa}$; MMP-9, $92 \mathrm{kDa} ; \beta$-actin, $45 \mathrm{kDa}$. ${ }^{* *} \mathrm{P}<0.01$ vs. control cells. uPA, urokinase plasminogen activator; MMP9, matrix metalloproteinases.

significant difference test using SPSS (version 17.0) software (SPSS Inc., Chicago, IL, USA). P<0.05 was considered to indicate a statistically significant difference.

\section{Results}

Curcumin inhibits the proliferation of colon cancer LoVo and SW480 cells. An MTT assay was performed to examine the effect of curcumin on the proliferation of colon cancer LoVo and SW480 cells. LoVo and SW480 cells were treated with various concentrations of curcumin $(0-50 \mu \mathrm{M})$ for $24 \mathrm{~h}$. Subsequently, curcumin markedly inhibited cell proliferation of colon cancer LoVo and SW480 cells in a dose-dependent manner $(\mathrm{P}=0.014$ and $\mathrm{P}=0.003$ vs. control cells, respectively; Fig. $1 \mathrm{~A}$ and $\mathrm{B}$ ). These inhibitory effects were observed following incubation with $1,10,20$ and $50 \mu \mathrm{M}$ curcumin. A dose of up to $20 \mu \mathrm{M}$ curcumin was used in further experiments.

Curcumin inhibits the invasion of colon cancer SW480 and LoVo cells. To investigate the effects of curcumin on the invasion of colon cancer SW480 and LoVo cells, a Matrigel-coated polycarbonate filter in a Boyden chamber was used. Following a $24 \mathrm{~h}$ incubation, curcumin was demonstrated to significantly decrease cell invasiveness. The number of SW480 cells that penetrated the membrane in $10 \mu \mathrm{M}$ curcumin-treated cells $(117.00 \pm 11.36)$ was significantly lower compared with control cells $(281.33 \pm 11.22)$ ( $\mathrm{P}=0.002$; Fig. 2A). The number of LoVo cells that penetrated the membrane in $10 \mu \mathrm{M}$ curcumin-treated cells $(188.30 \pm 15.03)$ was significantly lower compared with control cells $(76.03 \pm 5.77)$ $(\mathrm{P}=0.002$; Fig. 2B). These results demonstrate that curcumin has a significant inhibitory effect on the invasive activity of human colon cancer SW480 and LoVo cells.

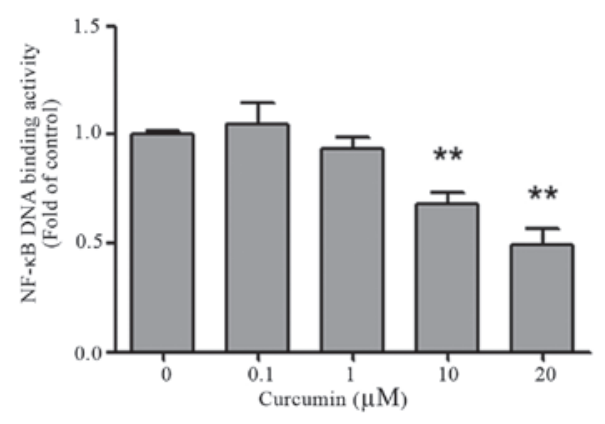

Figure 4. Effects of curcumin on NF- $\kappa B$ activation. Human colon SW480 and LoVo cells were pretreated with various concentrations of curcumin $(0-20 \mu \mathrm{M})$ for $24 \mathrm{~h}$. Nuclear extracts were prepared and NF- $\mathrm{kB}$ activation was measured by enzyme-linked immunosorbent assay. Quantified data are expressed as the mean \pm standard error of the mean of three experiments, and are an amalgama-

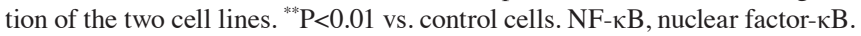

Curcumin inhibits the expression of MMP9 and $U P A$ in colon cancer LoVo and SW480 cells. To investigate whether curcumin affects the expression of UPA and MMP9, which are involved in tumor metastasis and invasion, western blotting and qPCR were performed. The protein and mRNA levels of uPA and MMP9 was dose-dependently decreased by curcumin in SW480 (Fig. 3A and B) and LoVo cells ( $\mathrm{P}=0.003$; Fig. $3 \mathrm{C}$ and $\mathrm{D}$ ). This data demonstrates that curcumin significantly decreases the expression of UPA and MMP9 in a dose-dependent manner, which results in the inhibitory effect of colon cancer cell adhesion and invasion.

Curcumin inhibits NF- $\kappa B$ activation in colon cancer LoVo and SW480 cells. The impact of curcumin on the NF-кB pathway 
A

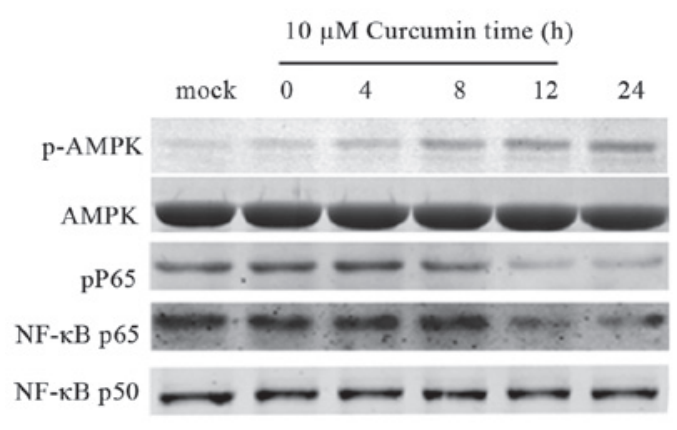

B

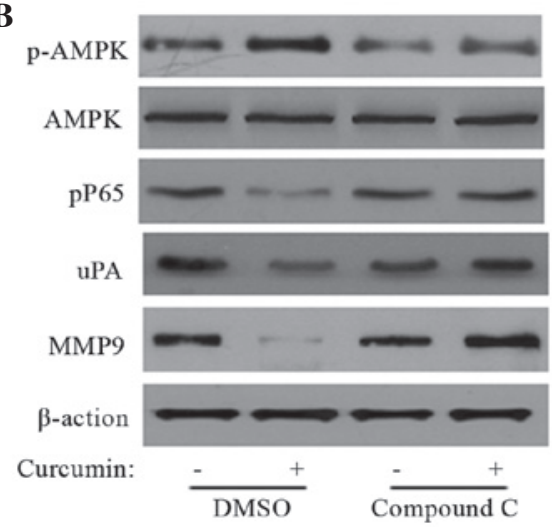

Figure 5. AMPK activation mediates curcumin-induced inhibition of NF-кB, uPA and MMP9. Human colon cancer SW480 cells were cultured until 70\% confluence. (A) Cells were treated with curcumin $(10 \mu \mathrm{M})$ for $0-24 \mathrm{~h}$ to investigate the effect on the NF- $\kappa$ B signaling pathway. (B) Cells were treated with curcumin $(10 \mu \mathrm{M})$ in the absence or presence of $10 \mu \mathrm{M}$ compound C, an AMPK inhibitor. Data are representative of three experiemnts. Band weights (kDa): uPA, $52 \mathrm{kDa}$; MMP-9, 92 kDa; $\beta$-actin, 45 kDa; p-AMPK, 62 kDa; AMPK, 62 kDa; pP65, 65 kDa; NF-кB p65, 65 kDa; NF-кB p50, 50kDa AMPK, 5' AMP-activated protein

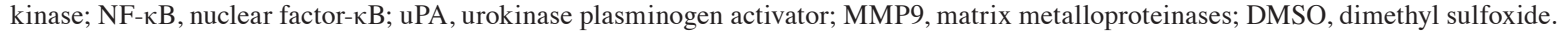
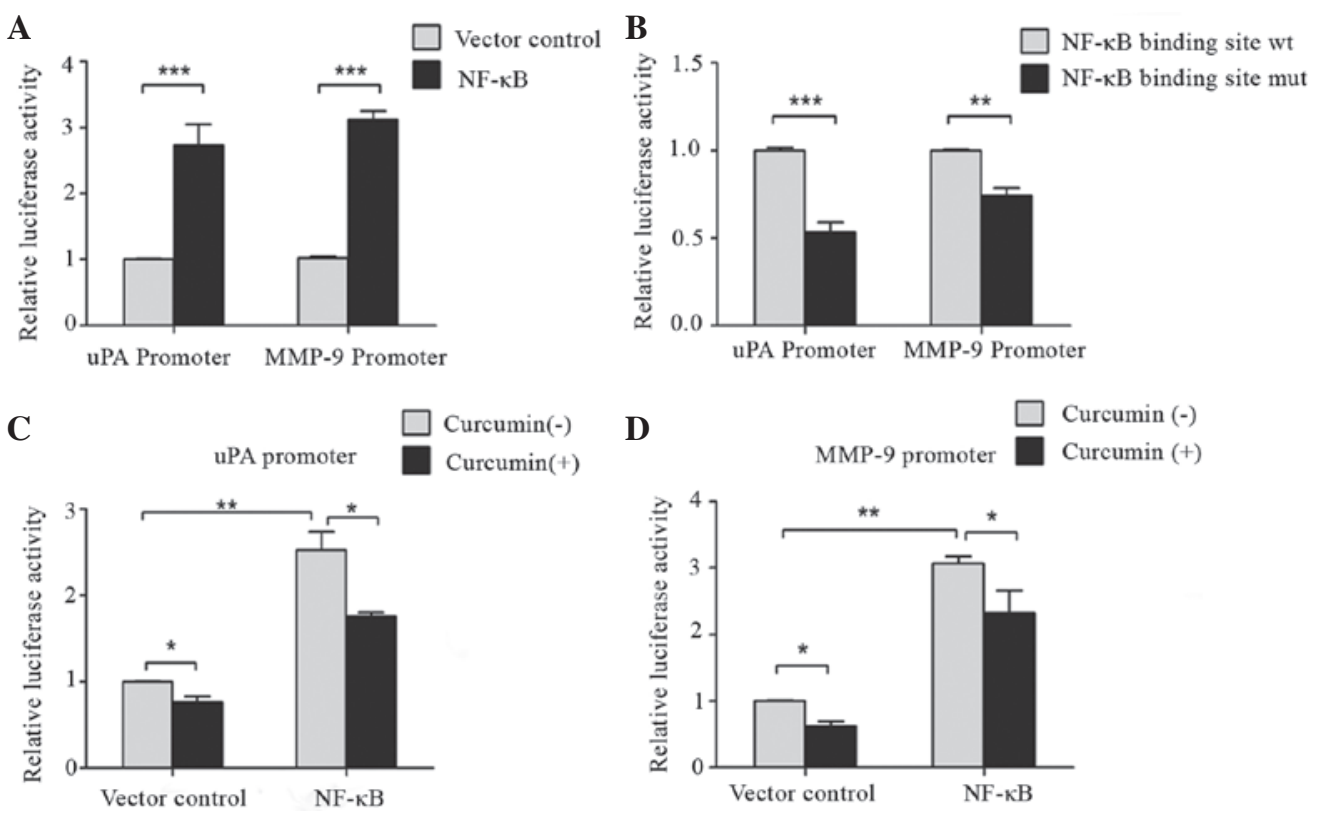

Figure 6. Curcumin inhibits p65 NF- $\mathrm{kB}$ DNA binding to the uPA and MMP9 promoter. (A) Luciferase assay was performed by co-transfection with uPA or MMP9 promoter reporter and HA-tagged $\mathrm{p} 65 \mathrm{NF}-\mathrm{\kappa B}$ expression plasmid. The uPA- and MMP9-specific promoter region activity increased dramatically in NF-kB-induced human colon cancer SW480 cells compared with the control. (B) Co-transfection with uPA and MMP9 promoters with mutated NF- $\mathrm{kB}$ binding sites and HA-tagged p65 NF- $\mathrm{kB}$ expression plasmid led to a significant decrease in activity compared with the control. (C and D) Co-transfection with (C) uPA and (D) MMP9 wild-type promoter reporter and HA-tagged p65 NF- $\mathrm{kB}$ expression plasmid in SW480 cells for $8 \mathrm{~h}$ and incubation with $10 \mu \mathrm{M}$ curcumin for $16 \mathrm{~h}$ led to a significant decrease in uPA and MMP9-specific promoter region activity. ${ }^{*} \mathrm{P}<0.05 ;{ }^{* *} \mathrm{P}<0.01 ;{ }^{* * *} \mathrm{P}<0.001$ vs. control. HA, human

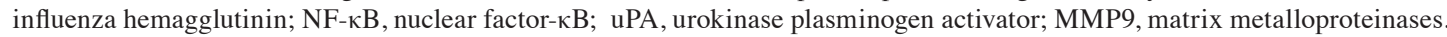

has been observed in multiple human carcinomas (33). To investigate whether curcumin affects NF-kB activation, which is critical for transcriptional activity, the DNA binding activity of NF- $\kappa \mathrm{B}$ was analyzed by ELISA. Colon cancer LoVo and SW480 cells were pretreated with various concentrations of curcumin $(0-20 \mu \mathrm{M})$ for $24 \mathrm{~h}$. As shown in Fig. 4, curcumin significantly decreased NF- $\mathrm{KB}$ activation in a dose-dependent manner for the two cells lines $(\mathrm{P}=0.002)$.

Curcumin inhibits NF- $\kappa B, u P A$ and MMP9 in colon cancer SW480 cells via AMPK activation. To investigate the effect of curcumin on the signaling pathway that regulates NF- $\mathrm{KB}$ activation, the present study investigated the expression of various proteins in SW480 cells using western blot analysis. SW480 cells was treated with $10 \mu \mathrm{M}$ curcumin at various time points $(0,4,8,12$ and $24 \mathrm{~h})$. As indicated in Fig. 5A, curcumin increased AMPK phosphorylation at Thr172 and downregulated NF- $\kappa \mathrm{B}$ p65 in a time-dependent manner.

To further delineate the role of AMPK in curcumin-induced inhibition of UPA and MMP9, pharmacological inhibition of AMPK was performed using compound $\mathrm{C}$. The inhibitory effect of compound C on AMPK activity was confirmed by western blot analysis. As shown in Fig. 5B, compound C abolished curcumin-induced inhibition of NF- $\kappa \mathrm{B}$, uPA and 
MMP9, suggesting that AMPK activation is responsible for curcumin-mediated NF- $\kappa \mathrm{B}$, uPA and MMP9 inhibition.

Curcumin inhibits p65 NF- $\kappa B$ DNA binding to the $u P A$ and $M M P 9$ promoter and its subsequent transactivation. Since several studies have demonstrated that NF- $\kappa \mathrm{B}$ is key in the transactivation of UPA and MMP9 (34-36), the present study investigated whether the activation of UPA and MMP9 may be attributed to $\mathrm{NF}-\kappa \mathrm{B}$. As shown in Fig. 6A, uPA- and MMP9-specific promoter region activity significantly increased in $\mathrm{NF}-\kappa \mathrm{B}$-induced SW480 cells compared with control cells $(\mathrm{P}=0.0006)$. Following mutations in the $\mathrm{NF}-\kappa \mathrm{B}$ binding site TTCC in UPA and MMP9 promoter regions, uPA and MMP9 activity decreased significantly compared with the control. This suggests that NF- $\kappa \mathrm{B}$ binds to the UPA and MMP9 promoter sequence TTCC ( $\mathrm{P}=0.0006$ and $\mathrm{P}=0.003$; Fig. $6 \mathrm{~B})$.

To further confirm the possibility that downregulation of uPA or MMP9 transactivation, resulting from curcumin treatment, was caused by reduced binding of NF- $\kappa \mathrm{B}$ to the $\mathrm{uPA}$ and MMP9 promoter sequence, wild-type UPA and MMP9 plasmids were transfected into SW480 cells for $8 \mathrm{~h}$, and the cells were incubated with $10 \mu \mathrm{M}$ curcumin for $16 \mathrm{~h}$. As shown in Fig. 6C and D, uPA- and MMP9-specific promoter region activity significantly decreased following curcumin treatment $(\mathrm{P}=0.012$; Fig. 6C), and treatment with $\mathrm{NF}-\kappa \mathrm{B}$ significantly upregulated uPA- and MMP9-specific promoter region activity $(\mathrm{P}=0.008$; Fig. 6D). Overall, these results indicate that curcumin has a significant inhibitory role in NF- $\mathrm{B}$--mediated binding transactivation of UPA and MMP9.

\section{Discussion}

Tumor cell metastasis is known as a complex cascade of events, which involves cell adhesion, ECM component degradation and tumor cell migration. Therefore, blocking one or more of these steps is required for anti-metastatic therapy (2). Curcumin, which has been demonstrated to be anti-tumorigenic, has well-documented chemopreventive properties in a number of cell types, including colon cancer cells $(21-25,37-40)$. The present study provides clear evidence that curcumin is capable of inhibiting the adhesion and invasion of human colon cancer cells through $\mathrm{NF}-\kappa \mathrm{B}$-dependent uPA and MMP9 activation and expression in a dose-dependent manner. This suggests that curcumin may possess anti-metastatic potential in human colon cancer.

The present data confirms that curcumin significantly inhibits colon cancer cell growth, particularly at a high concentration (41). Previous studies have revealed that $\mathrm{NF}-\kappa \mathrm{B}$ activation is critical for the proliferation, survival and metastasis of colon cancer cells $(26,41,42)$; therefore, inhibition of $\mathrm{NF}-\kappa \mathrm{B}$ activation is a potential antitumor strategy (43-46). The present study observed that curcumin dose-dependently suppresses constitutive $\mathrm{NF}-\kappa \mathrm{B}$ activation in colon cancer LoVo and SW480 cells. These results are in agreement with previous studies, which demonstrate that curcumin is a potent inhibitor of NF- $\kappa \mathrm{B}$ activation $(19,20)$. However, the potential mechanisms concerning $\mathrm{NF}-\kappa \mathrm{B}$ inhibition by curcumin leading to the suppression of colon cancer cell proliferation requires additional investigation.

$\mathrm{NF}-\kappa \mathrm{B}$ activation proceeds sequentially through the activation of IKK, phosphorylation of $\mathrm{IkB} \alpha$, degradation of $\mathrm{IkB} \alpha$, release of $\mathrm{NF}-\kappa \mathrm{B}, \mathrm{p} 65$ phosphorylation and p65 nuclear translocation (47). The present study investigated the expression of the different proteins in the $\mathrm{NF}-\kappa \mathrm{B}$ activation pathway by western blot analysis. Notably, the present study demonstrated that curcumin inhibited $N F-\kappa B$ via the activation of AMPK. The AMPK signaling pathway is important in maintaining cellular survival during stress by regulating metabolic homeostasis (48). Consistent with the present findings, previous studies have suggested that the activation of the AMPK pathway suppresses the function of the NF- $\kappa \mathrm{B}$ pathway (49-54). AMPK has certain direct phosphorylation targets (55); however, it is possible that AMPK inhibits $\mathrm{NF}-\kappa \mathrm{B}$ signaling through its downstream effectors, including peroxisome proliferator-activated receptor $\gamma$ co-activator $1 \alpha$ and sirtuin (silent mating type information regulation 2 homolog) 1, which suppress inflammatory factors.

Since little is known concerning the function of curcumin in colon cancer metastatic progression, the present study determined whether the colon cancer metastatic process is associated with the suppression of $\mathrm{NF}-\kappa \mathrm{B}$. The present cell-adhesion assay revealed that curcumin significantly reduced LoVo and SW480 cell adhesion to Matrigel (reconstituted basement membrane). This result led to additional investigation, which revealed that ECM molecules, including UPA and MMP9, were inhibited by curcumin. Numerous studies indicate that the key proteases involved in ECM degradation are MMP and serine proteases, including uPA and MMP9 $(7,11)$. The present study investigated UPA and MMP9 expression in colon cancer LoVo and SW480 cells. The present results demonstrated that curcumin significantly decreased the expression of UPA and MMP9 in a dose-dependent manner, which led to inhibitory effects on colon cancer cell adhesion and invasion. Since the level of p65 NF- $\kappa \mathrm{B}$ phosphorylation was decreased and phosphorylation of p65 is required for NF- $\kappa \mathrm{B}$ transcriptional activity (56), the present study further investigated the mechanism by which curcumin controls uPA and MMP9 activation and expression via activation of $\mathrm{NF}-\kappa \mathrm{B}$ in colon cancer cells. As expected, curcumin suppressed the binding of $\mathrm{p} 65 \mathrm{NF}-\kappa \mathrm{B}$ to the $\mathrm{uPA}$ and MMP9 promoter. These results clearly indicate that curcumin may inhibit uPA and MMP9 transcription by suppressing NF- $\kappa$ B DNA binding activity to uPA and MMP9 promoter region. Therefore, the anti-metastatic effects of curcumin in human colon cancer may be mediated by inhibition of the $\mathrm{NF}-\kappa \mathrm{B}$ signaling pathway.

In summary, the present preliminary investigation has revealed that the anti-metastatic effect of curcumin in colon cancer cells may be mediated by the decrease of uPA and MMP9 expression via NF- $\kappa \mathrm{B}$ activation. The NF- $\kappa \mathrm{B}$ signaling pathway promotes the activation of UPA and MMP9 signaling to regulate colon cancer cell invasion. In addition, curcumin dose-dependently suppresses the activation of NF- $\kappa \mathrm{B}$, and this effect may attribute to a dose-dependent decrease in uPA and MMP9 protein levels by binding to their promoter regions. The present study provides additional evidence that curcumin inhibits metastatic activity in cancer cells and reveals a novel therapeutic potential for curcumin for anti-metastatic therapy.

\section{References}

1. Fearon ER and Vogelstein B: A genetic model for colorectal tumorigenesis. Cell 61: 759-767, 1990 . 
2. Brooks SA, Lomax-Browne HJ, Carter TM, Kinch CE and Hall DM: Molecular interactions in cancer cell metastasis. Acta Histochem 112: 3-25, 2010.

3. Raghu H, Sodadasu PK, Malla RR, Gondi CS, Estes N and Rao JS: Localization of UPAR and MMP-9 in lipid rafts is critical for migration, invasion and angiogenesis in human breast cancer cells. BMC Cancer 10: 647, 2010.

4. Andreasen PA, Egelund R and Petersen HH: The plasminogen activation system in tumor growth, invasion, and metastasis. Cell Mol Life Sci 57: 25-40, 2000.

5. Vihinen P, Ala-aho R and Kähäri VM: Matrix metalloproteinases as therapeutic targets in cancer. Curr Cancer Drug Targets 5 203-220, 2005

6. Hildenbrand R, Gandhari M, Stroebel P, Marx A, Allgayer H and Arens N: The urokinase-system - role of cell proliferation and apoptosis. Histol Histopathol 23: 227-236, 2008.

7. Andreasen PA, Kjøller L, Christensen L and Duffy MJ: The urokinase-type plasminogen activator system in cancer metastasis: A review. Int J Cancer 72: 1-22, 1997.

8. Visse R and Nagase H: Matrix metalloproteinases and tissue inhibitors of metalloproteinases: Structure, function, and biochemistry. Circ Res 92: 827-839, 2003.

9. Newell KJ, Witty JP, Rodgers WH and Matrisian LM Expression and localization of matrix-degrading metalloproteinases during colorectal tumorigenesis. Mol Carcinog 10: 199-206, 1994.

10. Crowley CW, Cohen RL, Lucas BK, Liu G, Shuman MA and Levinson AD: Prevention of metastasis by inhibition of the urokinase receptor. Proc Natl Acad Sci USA 90: 5021-5025, 1993.

11. Roy R, Yang J and Moses MA: Matrix metalloproteinases as novel biomarkers and potential therapeutic targets in human cancer. J Clin Oncol 27: 5287-5297, 2009.

12. Baichwal VR: Activate NF-kappa B or die? Curr Biol 7: R94-R96, 1997.

13. Beg AA and Baltimore D: An essential role for NF-kappaB in preventing TNF-alpha-induced cell death. Science 274: 782-784, 1996.

14. Verma IM and Stevenson J: IkappaB kinase: Beginning, not the end. Proc Natl Acad Sci USA 94: 11758-11760, 1997.

15. Chen ZJ, Parent L and Maniatis T: Site-specific phosphorylation of IkappaBalpha by a novel ubiquitination-dependent protein kinase activity. Cell 84: 853-862, 1996.

16. Shishodia $\mathrm{S}$ and Aggarwal BB: Nuclear factor-kappaB activation: A question of life or death. J Biochem Mol Biol 35: 28-40, 2002.

17. Hatcher H, Planalp R, Cho J, Torti FM and Torti SV: Curcumin: From ancient medicine to current clinical trials. Cell Mol Life Sci 65: 1631-1652, 2008.

18. Aggarwal BB, Kumar A and Bharti AC: Anticancer potential of curcumin: Preclinical and clinical studies. Anticancer Res 23: 363-398, 2003

19. Singh S and Aggarwal BB: Activation of transcription factor NF-kappa B is suppressed by curcumin (diferuloylmethane) [corrected]. J Biol Chem 270: 24995-25000, 1995.

20. Kumar A, Dhawan S, Hardegen NJ and Aggarwal BB: Curcumin (Diferuloylmethane) inhibition of tumor necrosis factor (TNF)-mediated adhesion of monocytes to endothelial cells by suppression of cell surface expression of adhesion molecules and of nuclear factor-kappaB activation. Biochem Pharmacol 55 775-783, 1998

21. Shi M, Cai Q, Yao L, Mao Y, Ming Y and Ouyang G: Antiproliferation and apoptosis induced by curcumin in human ovarian cancer cells. Cell Biol Int 30: 221-226, 2006.

22. Kawamori T, Lubet R, Steele VE, Kelloff GJ, Kaskey RB, Rao CV and Reddy BS: Chemopreventive effect of curcumin, a naturally occurring anti-inflammatory agent, during the promotion/progression stages of colon cancer. Cancer Res 59: 597-601, 1999.

23. Mukhopadhyay A, Bueso-Ramos C, Chatterjee D, Pantazis P and Aggarwal BB: Curcumin downregulates cell survival mechanisms in human prostate cancer cell lines. Oncogene 20: 7597-7609, 2001

24. Bharti AC, Donato $\mathrm{N}$ and Aggarwal BB: Curcumin (diferuloylmethane) inhibits constitutive and IL-6-inducible STAT3 phosphorylation in human multiple myeloma cells. J Immunol 171: 3863-3871, 2003.

25. Kunnumakkara AB, Anand P and Aggarwal BB: Curcumin inhibits proliferation, invasion, angiogenesis and metastasis of different cancers through interaction with multiple cell signaling proteins. Cancer Lett 269: 199-225, 2008
26. Plummer SM, Holloway KA, Manson MM, Munks RJ, Kaptein A, Farrow S and Howells L: Inhibition of cyclo-oxygenase 2 expression in colon cells by the chemopreventive agent curcumin involves inhibition of NF-kappaB activation via the NIK/IKK signalling complex. Oncogene 18: 6013-6020, 1999.

27. Mohan R, Sivak J, Ashton P, Russo LA, Pham BQ, Kasahara N, Raizman MB and Fini ME: Curcuminoids inhibit the angiogenic response stimulated by fibroblast growth factor- 2 , including expression of matrix metalloproteinase gelatinase B. J Biol Chem 275: 10405-10412, 2000.

28. Pan MH, Lin-Shiau SY and Lin JK: Comparative studies on the suppression of nitric oxide synthase by curcumin and its hydrogenated metabolites through down-regulation of IkappaB kinase and NFkappaB activation in macrophages. Biochem Pharmacol 60: 1665-1676, 2000.

29. Jobin C, Bradham CA, Russo MP, Juma B, Narula AS, Brenner DA and Sartor RB: Curcumin blocks cytokine-mediated NF-kappaB activation and proinflammatory gene expression by inhibiting inhibitory factor I-kappa B kinase activity. J Immunol 163: 3474-3483, 1999

30. Cheng AL, Hsu CH, Lin JK, Hsu MM, Ho YF, Shen TS, Ko JY, Lin JT, Lin BR, Ming-Shiang W, et al: Phase I clinical trial of curcumin, a chemopreventive agent, in patients with high-risk or pre-malignant lesions. Anticancer Res 21: 2895-2900, 2001.

31. Al-Tubuly AA: SDS-PAGE and western blotting. Methods Mol Med 40: 391-405, 2000

32. Livak KI and Schmittgen TD: Analysis of relative gene expression data using real-time quantitative PCR and the 2(-Delta Delta C(T)) Method. Methods 25: 402-408, 2001.

33. Sandur SK, Deorukhkar A, Pandey MK, Pabón AM, Shentu S, Guha S, Aggarwal BB and Krishnan S: Curcumin modulates the radiosensitivity of colorectal cancer cells by suppressing constitutive and inducible NF-kappaB activity. Int J Radiat Oncol Biol Phys 75: 534-542, 2009.

34. Killeen SD, Wang JH, Andrews EJ and Redmond HP: Bacterial endotoxin enhances colorectal cancer cell adhesion and invasion through TLR-4 and NF-kappaB-dependent activation of the urokinase plasminogen activator system. Br J Cancer 100: $1589-1602,2009$

35. Sliva D, English D, Lyons D and Lloyd FP Jr: Protein kinase C induces motility of breast cancers by upregulating secretion of urokinase-type plasminogen activator through activation of AP-1 and NF-kappaB. Biochem Biophys Res Commun 290: 552-557, 2002.

36. Tsunoda K, Kitange G, Anda T, Shabani HK, Kaminogo M, Shibata $S$ and Nagata I: Expression of the constitutively activated RelA/NF-kappaB in human astrocytic tumors and the in vitro implication in the regulation of urokinase-type plasminogen activator, migration, and invasion. Brain Tumor Pathol 22: 79-87, 2005.

37. Bharti AC, Donato N, Singh S and Aggarwal BB: Curcumin (diferuloylmethane) down-regulates the constitutive activation of nuclear factor-kappa B and IkappaBalpha kinase in human multiple myeloma cells, leading to suppression of proliferation and induction of apoptosis. Blood 101: 1053-1062, 2003.

38. Zong H, Wang F, Fan QX and Wang LX: Curcumin inhibits metastatic progression of breast cancer cell through suppression of urokinase-type plasminogen activator by NF-kappa B signaling pathways. Mol Biol Rep 39: 4803-4808, 2012

39. Shishodia S, Amin HM, Lai R and Aggarwal BB: Curcumin (diferuloylmethane) inhibits constitutive NF-kappaB activation, induces G1/S arrest, suppresses proliferation, and induces apoptosis in mantle cell lymphoma. Biochem Pharmacol 70: 700-713, 2005.

40. Shishodia S, Potdar P, Gairola CG and Aggarwal BB: Curcumin (diferuloylmethane) down-regulates cigarette smoke-induced NF-kappaB activation through inhibition of IkappaBalpha kinase in human lung epithelial cells: Correlation with suppression of COX-2, MMP-9 and cyclin D1. Carcinogenesis 24: 1269-1279, 2003.

41. Johnson SM, Gulhati P, Arrieta I, Wang X, Uchida T, Gao T and Evers BM: Curcumin inhibits proliferation of colorectal carcinoma by modulating Akt/mTOR signaling. Anticancer Res 29: 3185-3190, 2009.

42. Chen H, Zhang ZS, Zhang YL and Zhou DY: Curcumin inhibits cell proliferation by interfering with the cell cycle and inducing apoptosis in colon carcinoma cells. Anticancer Res 19: 3675-3680, 1999.

43. Baeuerle PA and Baichwal VR: NF-kappa B as a frequent target for immunosuppressive and anti-inflammatory molecules. Adv Immunol 65: 111-137, 1997. 
44. Garg A and Aggarwal BB: Nuclear transcription factor-kappaB as a target for cancer drug development. Leukemia 16: 1053-1068, 2002.

45. Huang S, Pettaway CA, Uehara H, Bucana CD and Fidler IJ: Blockade of NF-kappaB activity in human prostate cancer cells is associated with suppression of angiogenesis, invasion, and metastasis. Oncogene 20: 4188-4197, 2001.

46. Hideshima T, Chauhan D, Richardson P, Mitsiades C, Mitsiades N, Hayashi T, Munshi N, Dang L, Castro A, Palombella V, et al NF-kappa B as a therapeutic target in multiple myeloma. J Biol Chem 277: 16639-16647, 2002.

47. Ghosh $\mathrm{S}$ and Karin M: Missing pieces in the NF-kappaB puzzle. Cell (109 Suppl): S81-S96, 2002

48. Salminen A, Hyttinen JM and Kaarniranta K: AMP-activated protein kinase inhibits NF-kappaB signaling and inflammation: Impact on healthspan and lifespan. J Mol Med (Berl) 89: 667-676, 2011.

49. Bai A, Ma AG, Yong M, Weiss CR, Ma Y, Guan Q, Bernstein CN and Peng Z: AMPK agonist downregulates innate and adaptive immune responses in TNBS-induced murine acute and relapsing colitis. Biochem Pharmacol 80: 1708-1717, 2010.

50. Yang Z, Kahn BB, Shi H and Xue BZ: Macrophage alpha1 AMP-activated protein kinase (alpha1AMPK) antagonizes fatty acid-induced inflammation through SIRT1. J Biol Chem 285: 19051-19059, 2010.
51. Sag D, Carling D, Stout RD and Suttles J: Adenosine 5'-monophosphate-activated protein kinase promotes macrophage polarization to an anti-inflammatory functional phenotype. J Immunol 181: 8633-8641, 2008.

52. Wang S, Zhang M, Liang B, Xu J, Xie Z, Liu C, Viollet B, Yan D and Zou MH: AMPKalpha2 deletion causes aberrant expression and activation of $\mathrm{NAD}(\mathrm{P}) \mathrm{H}$ oxidase and consequent endothelial dysfunction in vivo: Role of $26 \mathrm{~S}$ proteasomes. Circ Res 106: $1117-1128,2010$

53. Wu X, Mahadev K, Fuchsel L, Ouedraogo R, Xu SQ and Goldstein BJ: Adiponectin suppresses IkappaB kinase activation induced by tumor necrosis factor-alpha or high glucose in endothelial cells: Role of cAMP and AMP kinase signaling. Am J Physiol Endocrinol Metab 293: E1836-E1844, 2007.

54. Hattori Y, Suzuki K, Hattori S and Kasai K: Metformin inhibits cytokine-induced nuclear factor kappaB activation via AMP-activated protein kinase activation in vascular endothelial cells. Hypertension 47: 1183-1188, 2006.

55. Cantó C and Auwerx J: AMP-activated protein kinase and its downstream transcriptional pathways. Cell Mol Life Sci 67: 3407-3423, 2010.

56. Zhong H, Voll RE and Ghosh S: Phosphorylation of NF-kappa B p65 by PKA stimulates transcriptional activity by promoting a novel bivalent interaction with the coactivator $\mathrm{CBP} / \mathrm{p} 300$. Mol Cell 1: 661-671, 1998. 